\title{
Digestive System Small Cell Carcinoma
}

National Cancer Institute

\section{Source}

National Cancer Institute. Digestive System Small Cell Carcinoma. NCI Thesaurus. Code C154641.

An aggressive, high-grade, and poorly differentiated carcinoma with neuroendocrine differentiation that arises from any part of the gastrointestinal system. It is characterized by the presence of malignant small cells. 